\title{
THE EFFECT OF A SINGLE INJECTION OF CONCENTRATED HUMAN SERUM ALBUMIN ON CIRCULATING PROTEINS AND PROTEINURIA IN NEPHROSIS ${ }^{1}$
}

\author{
By JOHN A. LUETSCHER, JR. \\ (From the Chemical Division, Medical Clinic, Johns Hopkins University and Hospital, Baltimore)
}

(Received for publication November 12, 1943)

The intravenous injection of concentrated human serum or plasma into patients with hypoproteinemia of the nephrotic syndrome has not generally produced the desired rise in serum protein concentration (1 to 3$)$. Diuresis and loss of edema are usually disappointing and rarely permanent.

Study of the serum proteins and hematocrit $(2,3)$ would seem to indicate that the injected plasma was soon withdrawn from the circulation, with little effect on the original serum albumin or globulin concentration. Not more than half of the injected protein appeared in the urine. In dogs with nutritional edema, injected protein was quickly removed from the circulating blood without any loss of protein in the urine (4).

In order to study the movements of protein and fluid, a single injection of concentrated human serum albumin has been given to 3 patients suffering from the nephrotic syndrome. Since this material is electrophoretically homogeneous, the injected protein can be traced when sufficiently large amounts are injected and when the plasma volume is determined concurrently.

\section{MATERIAL AND METHODS}

The purified human serum albumin was prepared in the Plasma Fractionation Laboratory of the Harvard Medical School.1 The method earlier in use there for the preparation of this fraction was developed by Cohn, et al. (5).

Plasma protein determinations were made by $\mathrm{Kjeldahl}$ nitrogen determination. Urine protein was determined by dry weight.

The electrophoresis apparatus of Tiselius as modified by Longsworth (6) was used to study the protein distribution. With cloudy serum, large variations of photographic exposure on the recording plate displace the light-shadow boundary unequally and lead to considerable error. The use of a horizontal slit instead of a single knife-edge for scanning deflection of light avoids this error, since the

1 The concentrated human serum albumin used in this work was produced under contract, recommended by the Committee on Medical Research, between the Office of Scientific Research Development and Harvard University. recorded diagram is then outlined by a narrow line of exposure which is not displaced by over- or under-exposure of the photographic plate.

The buffer used in the electrophoresis of serum affects the relative mobilities of the protein fractions (6). The fraction described in a previous report (7) as $\alpha$-globulin, appearing in phosphate buffer of ionic strength 0.2 and $\mathrm{pH} 7.8$, is the same as Tiselius $\alpha$-globulin. The fraction described in the present study as $\alpha_{1}$ appears just behind the albumin boundary, in veronal buffer of ionic strength 0.1 , at $\mathrm{pH} 8.6$, and is apparently not the same as Tiselius' $\alpha$-globulin, which cannot be accurately differentiated from the large $\beta$-globulin peak in nephrotic serum in the veronal buffer.

The plasma volume was determined with the blue dye T-1824, with suitable corrections for the diminution in the cloudiness of the serum which follows the injection of serum albumin. If such a correction is not applied, the fall in optical density of the serum indicates an erroneously high dilution of the dye. An equation for the corrected L620 can be set up in the same form as the usual correction for hemolysis but with different constants. If no hemolysis is present, the optical density at $540 \mathrm{~m} \mu$ may be used, but it may be preferable to use a wave length less sensitive to traces of hemoglobin. The ratio of optical density at $620 \mathrm{~m} \mu$ to that at the indifferent wave length is independent of dilution, both for dye and for cloudiness, within the usual range. The ratios may therefore be considered as constants and substituted in a general equation as follows:

$\frac{\mathrm{L} 620}{\mathrm{~L} 540}$ due to cloudinees $=K$ (determined from blank serum $)$

$\frac{\mathrm{L} 620}{\mathrm{L540}}$ due to dye $\quad=K^{\prime}$ (determined from dye)

L620 due to dye $=\frac{\text { Observed L620 }-(K \times \text { observed L540 })}{1-\left(K / K^{\prime}\right)}$

The colloid osmotic pressure of the serum was determined with the Hepp osmometer $(8, a$. and b.).

All patients were young adults with an insidious onset of edema, presenting the characteristic features of the nephrotic syndrome. Patients I and II were obviously edematous, but patient III seldom had perceptible edema on a salt-free diet. In all cases at the time of the study, the heart was normal, blood pressure was not elevated, and there was no reduction in phenolsulfonphthalein excretion, urea clearance, or concentrating power of the kidney. On other occasions, patients I and III had some hypertension and microscopic hematuria, but these manifestations were never observed in patient II. 
TABLE I

Electrophoretic analysis of proteins of serum and urine

\begin{tabular}{|c|c|c|c|c|c|c|}
\hline \multirow{2}{*}{ Case } & \multirow{2}{*}{ Time } & \multirow{2}{*}{ Fluid } & \multirow{2}{*}{$\underset{\mathrm{min}}{\text { Albu- }}$} & \multirow{2}{*}{$\alpha_{1}$} & \multicolumn{2}{|c|}{ Globulins } \\
\hline & & & & & $\alpha_{2}+\beta$ & $\gamma$ \\
\hline I & $\begin{array}{l}\text { Control } \\
\text { Control day I } \\
\text { Control day II } \\
\text { Post-injection } \\
\text { 2nd day } \\
\text { 3rd day }\end{array}$ & $\begin{array}{l}\text { serum } \\
\text { urine } \\
\text { urine } \\
\text { serum } \\
\text { urine } \\
\text { urine } \\
\text { serum } \\
\text { urine }\end{array}$ & $\begin{array}{r}\text { per } \\
13.0 \\
46.1 \\
46.4 \\
30.1 \\
70.7 \\
58.5 \\
15.0 \\
55.3\end{array}$ & $\begin{array}{r}\text { ent } \\
7.2 \\
20.4 \\
20.5 \\
5.7 \\
10.3 \\
15.4 \\
6.4 \\
15.7\end{array}$ & $\begin{array}{r}\text { per } \\
74.2 \\
20.5 \\
21.2 \\
59.9 \\
13.2 \\
17.9 \\
73.0 \\
18.8\end{array}$ & $\begin{array}{r}\text { ent } \\
5.6 \\
13.0 \\
11.9 \\
4.3 \\
5.8 \\
8.2 \\
5.6 \\
10.2\end{array}$ \\
\hline II & $\begin{array}{l}\text { Control } \\
\text { Post-injection } \\
\text { 2nd day } \\
\text { 3rd day }\end{array}$ & $\begin{array}{l}\text { serum } \\
\text { urine } \\
\text { serum } \\
\text { urine } \\
\text { serum } \\
\text { urine } \\
\text { serum } \\
\text { urine }\end{array}$ & $\begin{array}{l}17.2 \\
65.3 \\
23.9 \\
79.9 \\
20.0 \\
75.4 \\
18.6 \\
67.5\end{array}$ & $\begin{array}{r}3.9 \\
11.2 \\
2.5 \\
6.9 \\
4.2 \\
8.7 \\
4.0 \\
12.5\end{array}$ & $\begin{array}{r}72.5 \\
15.0 \\
66.9 \\
8.7 \\
68.0 \\
9.7 \\
69.5 \\
12.2\end{array}$ & $\begin{array}{l}6.4 \\
8.5 \\
6.7 \\
4.5 \\
7.8 \\
6.2 \\
7.9 \\
7.8\end{array}$ \\
\hline III & $\begin{array}{l}\text { Control } \\
\text { Post-injection } \\
\text { 2nd day }\end{array}$ & $\begin{array}{l}\text { serum } \\
\text { urine } \\
\text { serum } \\
\text { urine } \\
\text { serum }\end{array}$ & $\begin{array}{l}15.0 \\
62.6 \\
29.2 \\
90.8 \\
19.1\end{array}$ & $\begin{array}{r}14.4 \\
4.6\end{array}$ & $\begin{array}{r}79.4 \\
19.3 \\
66.1 \\
3.6 \\
75.5\end{array}$ & $\begin{array}{l}5.6 \\
3.7 \\
4.7 \\
1.0 \\
5.4\end{array}$ \\
\hline
\end{tabular}

RESULTS

In control observations, all patients had a large initial deficit of plasma and red blood cell volumes. The plasma volumes ranged from
70 to 82 per cent on the expected normal, and red blood cell volumes from 54 to 80 per cent. When the lowered concentration of serum protein is also considered, the deficit of total circulating protein and especially albumin is even greater. The electrophoretic analyses (Table I) showed the usual nephrotic pattern with diminished albumin and $\gamma$-globulin and increased $\beta$-globulin in the serum. Colloid osmotic pressures were far below the normal range (Table II). The urine contained proportionately more albumin and less $\beta$-globulin than the serum.

\section{Effects of injection of serum albumin}

Plasma volume. The plasma volume rose sharply as the protein was injected (Figure 1). This was reflected both in the fall in dye concentration and in the lowered hematocrit determinations. Of the two, the hematocrit indicated the larger increase in plasma volume. This is notable, since the dye T-1824 is closely associated with the serum proteins and might be removed from the circulation with the albumin. There is no evidence for such an increased rate of disappearance.

Serum protein concentration. There was little immediate change in the concentration of pro-

TABLE II

Changes in plasma volume, circulating protein, and colloid osmotic pressure after injection of concentrated serum albumin

\begin{tabular}{|c|c|c|c|c|c|c|c|c|c|c|}
\hline \multirow{2}{*}{ Patient } & \multirow{2}{*}{ Time } & \multirow{2}{*}{$\begin{array}{l}\text { Plasma } \\
\text { volume }\end{array}$} & \multirow{2}{*}{$\underset{\text { protein }}{\text { Serum }}$} & \multicolumn{3}{|c|}{ Total circulating } & \multicolumn{2}{|c|}{$\begin{array}{l}\text { Gain or loss trom } \\
\text { time of injection }\end{array}$} & \multirow{2}{*}{$\begin{array}{l}\text { Colloid } \\
\text { osmotic } \\
\text { pressure }\end{array}$} & \multirow{2}{*}{ Hematocrit } \\
\hline & & & & Protein & Albumin & Globulin & Albumin & Globulin & & \\
\hline I & $\begin{array}{l}\text { Control } \\
\text { Calculated } \\
\text { End of injection } \\
30 \text { minutes } \\
1 \text { hour } \\
6 \text { hours } \\
48 \text { hours }\end{array}$ & $\begin{array}{c}c c . \\
1800 \\
2300 \\
2350 \\
2280 \\
1920 \\
1780\end{array}$ & $\begin{array}{c}\text { grams } \\
\text { per } \\
100 \mathrm{cc} . \\
3.40 \\
\\
3.58 \\
3.48 \\
3.36 \\
3.51 \\
3.72\end{array}$ & $\begin{array}{l}\text { grams } \\
\\
61.2 \\
86.2 \\
82.3 \\
81.8 \\
76.6 \\
67.5 \\
66.2\end{array}$ & $\begin{array}{r}\text { grams } \\
\\
8.0 \\
33.0 \\
24.6 \\
\\
9.9\end{array}$ & $\begin{array}{c}\text { grams } \\
53.2 \\
53.2 \\
57.2 \\
56.3\end{array}$ & $\begin{array}{l}+25.0 \\
-8.4 \\
-23.1\end{array}$ & $\begin{array}{l}+4.0 \\
+3.1\end{array}$ & $\begin{array}{l}117 \\
116 \\
109\end{array}$ & $\begin{array}{l}35.2 \\
28.5 \\
26.9 \\
26.8 \\
32.0 \\
33.5\end{array}$ \\
\hline II & $\begin{array}{l}\text { Control } \\
\text { Calculated } \\
20 \text { minutes } \\
40 \text { minutes } \\
1 \text { hour } \\
6 \text { hours } \\
24 \text { hours } \\
48 \text { hours }\end{array}$ & $\begin{array}{l}2510 \\
3120 \\
3070 \\
3080 \\
3000 \\
3080 \\
2980\end{array}$ & $\begin{array}{l}3.14 \\
3.09 \\
3.09 \\
3.00 \\
2.81 \\
2.50 \\
2.26\end{array}$ & $\begin{array}{r}78.8 \\
103.8 \\
96.2 \\
95.0 \\
92.4 \\
84.3 \\
77.0 \\
67.2\end{array}$ & $\begin{array}{l}13.6 \\
38.6 \\
22.1 \\
\\
15.4 \\
12.5\end{array}$ & $\begin{array}{l}65.2 \\
65.2 \\
70.3 \\
61.6 \\
54.7\end{array}$ & $\begin{array}{l}+25.0 \\
-16.3 \\
-23.1 \\
-26.0\end{array}$ & $\begin{array}{l}+5.3 \\
-\quad 3.4 \\
-11.3\end{array}$ & $\begin{array}{r}108 \\
120 \\
118 \\
118 \\
98 \\
86\end{array}$ & $\begin{array}{l}41.4 \\
35.5 \\
35.6 \\
35.4 \\
35.1 \\
35.0 \\
35.9\end{array}$ \\
\hline III & $\begin{array}{l}\text { Control } \\
\text { Calculated } \\
30 \text { minutes } \\
24 \text { hours }\end{array}$ & $\begin{array}{l}1820 \\
2340 \\
1910\end{array}$ & $\begin{array}{l}3.70 \\
3.70 \\
3.75\end{array}$ & $\begin{array}{l}67.3 \\
92.3 \\
86.6 \\
71.6\end{array}$ & $\begin{array}{l}10.1 \\
35.1 \\
25.3 \\
13.6\end{array}$ & $\begin{array}{l}\mathbf{5 7 . 2} \\
\mathbf{5 7 . 2} \\
\mathbf{6 1 . 3} \\
\mathbf{5 8 . 0}\end{array}$ & $\begin{array}{l}+25 \\
-9.8 \\
-21.5\end{array}$ & $\begin{array}{r} \\
+\quad 4.1 \\
+\quad 0.8\end{array}$ & & $\begin{array}{l}48.2 \\
39.5 \\
43.8\end{array}$ \\
\hline
\end{tabular}



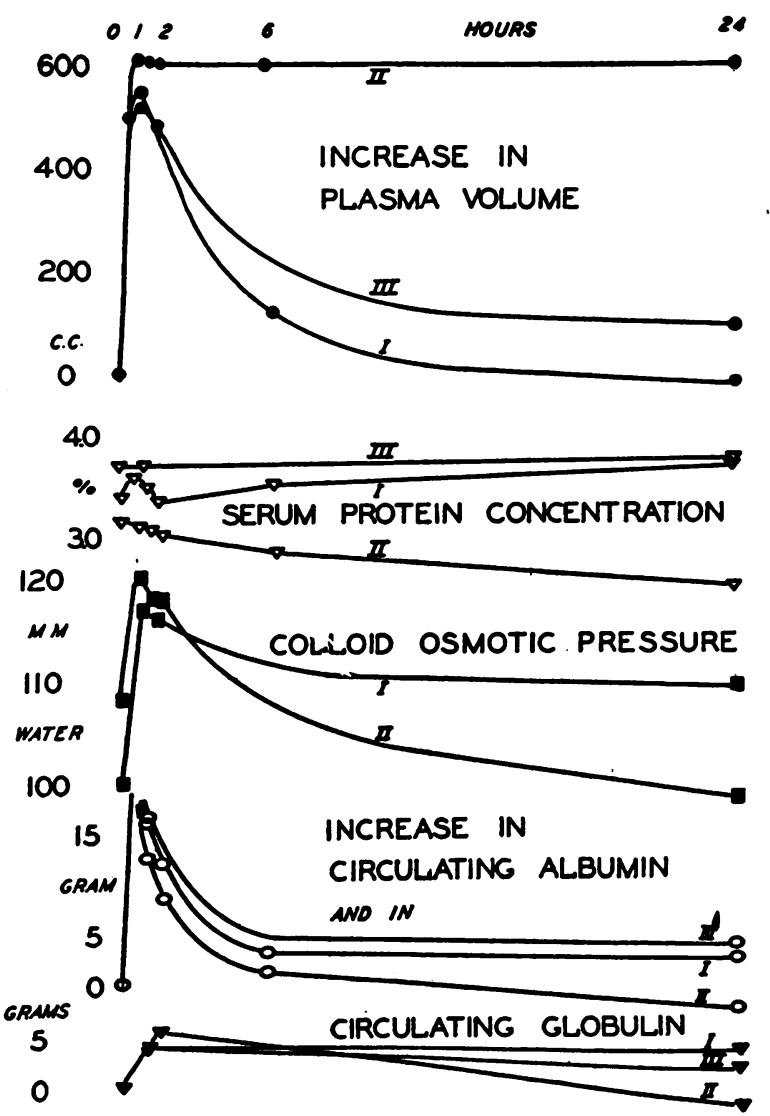

Fig. 1. Effect of Injection of Serum Albumin on Plasma Volume, Serum Protein Concentration, Colloid Osmotic Pressure, and Circulating Albumin AND GLOBULIN

tein in the serum following a single injection of concentrated serum albumin. The concentrated protein solution must have been diluted or very rapidly removed from the circulation. In order to differentiate between these possibilities, it is necessary to calculate the total circulating serum protein.

Total circulating protein. When the serum protein concentration is multiplied by the plasma volume (expressed in appropriate units), the product represents grams of circulating serum protein. The product is far more informative than the individual factors, since a change in circulating protein may be reflected in variable changes in either concentration or plasma volume, depending on the exchange of fluid between the plasma and interstitial spaces in response to hydrostatic and osmotic forces. This is easily seen in Figure 1 in the contrast between case II on the one hand and cases I and III on the other. In all cases, there was a rapid fall in circulating protein after the injection, but the mechanism was not the same. In cases I and II, it was largely at the expense of the plasma volume, with the serum protein concentration stationary or rising slightly. In case II, however, the plasma volume maintained its increase at the expense of the protein concentration. This difference in mechanism, interesting in itself, must for the present only emphasize the more consistent behavior of the total circulating serum protein.

The results of the injection of albumin are presented in Table II. There is an increase of circulating protein after the injection, followed by a progressive decrease. Since the total circulating serum protein is the sum of the albumin and several globulin fractions, which may vary independently, the quantitative changes are considered under the individual fractions.

Albumin and globulins. The serum protein distribution, as determined by the Tiselius
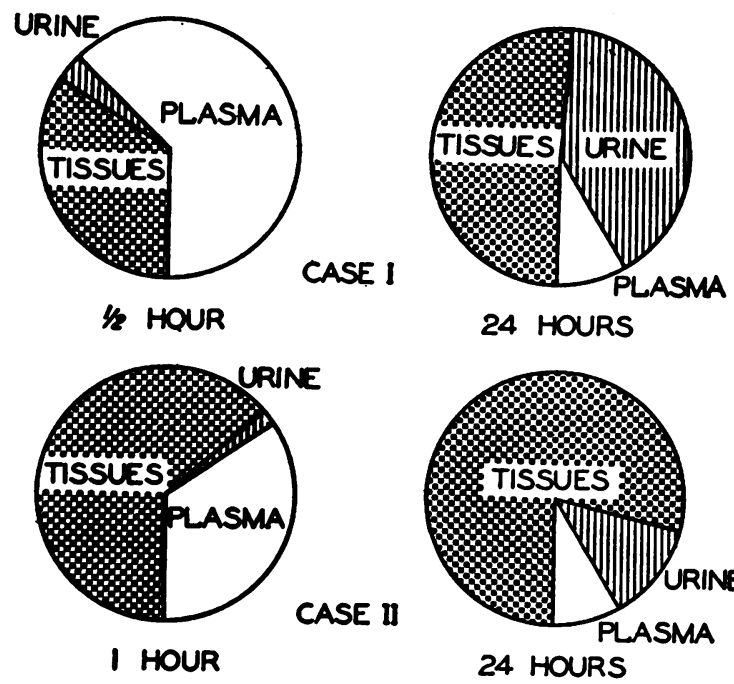

24 HOURS

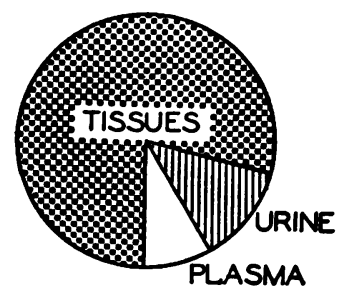

24 HOURS
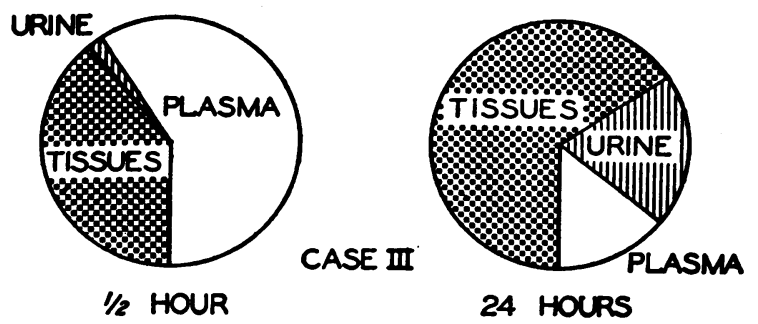

Fig. 2. Distribution of InJected Albumin between Plasma, Urine, and Tissues at Various Times after INJECTION 
apparatus, changed far less than expected. When the total circulating serum albumin and globulins are calculated (concentration multiplied by plasma volume), it is evident that large and rapid transfers of protein have occurred. A large amount of albumin has apparently disappeared from the circulation and an apprecible amount of globulin has appeared within 30 minutes of the end of the injection. The amount of protein lost in the urine during the period involved in these transfers was insignificant in comparison.

In order to rule out some unusual error in the Tiselius determinations, the nephrotic serum was mixed with pure serum albumin in vitro and analyzed in a similar fashion. The results were very close to the expected values (Table V). This experiment would seem to eliminate any large analytical error and also any property of the serum of these patients which might affect the analysis.

Colloid osmotic pressure of serum. The colloid osmotic pressure increased following the injection, as might have been predicted from the increased proportion of albumin with little change in protein concentration.

Circulatory readjustments. There was a transient increase in arterial blood pressure during the injection. The venous pressure was in-

TABLE III

Effect of albumin injection on proteinuria

\begin{tabular}{|c|c|c|c|c|c|c|c|c|c|}
\hline \multirow{2}{*}{ Case } & \multirow{2}{*}{ Day } & \multicolumn{4}{|c|}{ Protein in urine } & \multicolumn{4}{|c|}{ Protein clearance } \\
\hline & & $\begin{array}{l}\text { To- } \\
\text { tal }\end{array}$ & $\underset{\text { min }}{\text { Albu- }}$ & $\alpha_{1}$ & $\begin{array}{l}\text { Glob- } \\
\text { ulin }\end{array}$ & $\begin{array}{l}\text { To- } \\
\text { tal }\end{array}$ & $\underset{\text { min }}{\text { Albu- }}$ & $\alpha_{1}$ & $\begin{array}{l}\text { Glob- } \\
\text { ulin }\end{array}$ \\
\hline I & $\begin{array}{l}\text { Control } \\
\text { Injection } \\
\text { 2nd day } \\
\text { 3rd day }\end{array}$ & $\begin{array}{l}11.2 \\
17.8 \\
13.5 \\
12.6\end{array}$ & \begin{tabular}{|r|} 
grams \\
5.2 \\
12.6 \\
7.9 \\
7.0
\end{tabular} & $\begin{array}{l}2.3 \\
1.8 \\
2.1 \\
2.0\end{array}$ & \begin{tabular}{|l|}
3.7 \\
3.4 \\
3.5 \\
3.6
\end{tabular} & $\begin{array}{l}0.23 \\
0.36 \\
0.23\end{array}$ & $\begin{array}{l}\text { cc. per } \\
\begin{array}{l}0.82 \\
0.85 \\
0.85\end{array} \mid\end{array}$ & $\begin{array}{l}\text { minut } \\
0.65 \\
0.65 \\
0.56\end{array}$ & $\mid \begin{array}{l}0.10 \\
0.11 \\
0.09\end{array}$ \\
\hline II & $\begin{array}{l}\text { Control } \\
\text { Injection } \\
\text { 2nd day } \\
\text { 3rd day }\end{array}$ & $\begin{array}{r}8.1 \\
10.4 \\
8.1 \\
7.3\end{array}$ & $\begin{array}{l}5.3 \\
8.3 \\
6.1 \\
4.9\end{array}$ & $\begin{array}{l}0.9 \\
0.7 \\
0.7 \\
0.9\end{array}$ & $\begin{array}{l}1.9 \\
1.4 \\
1.3 \\
1.5\end{array}$ & $\begin{array}{l}0.18 \\
0.24 \\
0.22 \\
0.22\end{array}$ & $\left|\begin{array}{l}0.70 \\
0.80 \\
0.84 \\
0.80\end{array}\right|$ & $\begin{array}{l}0.52 \\
0.66 \\
0.46 \\
0.68\end{array}$ & $\begin{array}{l}0.05 \\
0.05 \\
0.05 \\
0.06\end{array}$ \\
\hline & \multicolumn{3}{|c|}{ 80-minute periods } & \multicolumn{2}{|c|}{$\begin{array}{c}\text { grams } \\
\text { per } \\
\text { hour }\end{array}$} & & & & \\
\hline III & $\begin{array}{l}\text { Before } \\
\text { After }\end{array}$ & $\begin{array}{l}0.341 \\
0.768\end{array} \mid$ & $\begin{array}{l}0.214 \\
0.698\end{array}$ & & $\begin{array}{l}27 \\
70\end{array}$ & $\begin{array}{l}0.15 \\
0.35\end{array}$ & $\begin{array}{l}0.64 \\
1.09\end{array}$ & & \\
\hline
\end{tabular}

In case III, $\alpha_{1}$ could not be accurately measured in the serum because of its low concentration.
TABLE IV

Effect of albumin injection on glomerular filtration and on the excretion of chloride, protein, and T-1824

Clearences are expressed in cc. of plasma per minute per sq. meter of body surface.

\begin{tabular}{l|c|c|c|c|c|c}
\hline \hline & Mannitol & Chloride & Protein & T-1824 & Albumin & Globulin \\
\hline Before & 101 & 0.35 & 0.09 & 0.37 & 0.39 & 0.030 \\
After & 177 & 0.25 & 0.21 & 0.75 & 0.66 & 0.030 \\
\hline
\end{tabular}

TABLE V

Analysis of mixtures of albumin with nephrotic serum in vitro

\begin{tabular}{l|r|r|r}
\hline \hline & Protein & \multicolumn{2}{|c}{ Albumin } \\
\cline { 2 - 3 } & mgm. & per cent & $m g m$. \\
SERUM A , & 108 & 8.8 & 9.5 \\
Albumin , & 32 & 100.0 & 32.0 \\
Mixture: calculated & 140 & 29.6 & 41.5 \\
observed & & 28.7 & \\
SERUM B & 119 & 17.9 & 21.3 \\
Albumin & 31 & 100.0 & 31.0 \\
Mixture: calculated & 150 & 34.9 & 52.3 \\
$\quad$ observed & & 35.3 & \\
\hline
\end{tabular}

creased by 10 to $30 \mathrm{~mm}$. of water during the injection. This rise was sustained for several hours.

Proteinuria. The loss of protein in the urine increased following the albumin injection. There was a rise both in the volume and in the protein concentration of the urine. The extra protein lost was entirely serum albumin, the daily globulin loss remaining nearly constant or diminishing somewhat (Table III). Within 2 days of the time of injection, proteinuria returned to the control level.

With a constant kidney status, the percentage of albumin in the urinary protein depends on the percentage of albumin in the serum protein, as suggested in a previous report (7). When the proportion of albumin in the serum was increased by the injection, the proportion of albumin in the urine became very large. With the subsequent fall in serum albumin, there was a fall in the proportion of albumin in the urinary protein (Figures 3, 4, and 5).

Albumin and globulin "clearance." The loss of protein in the urine may be compared with the concentration of protein in the blood plasma in the form of a clearance of plasma per minute. When this calculation is made on a daily basis, the albumin clearance and the globulin clearance 
are little affected by the albumin injection (Table III). The clearance of $\alpha_{1}$ is only slightly less than that of albumin and much greater than that of globulin. In case III, during the albu-

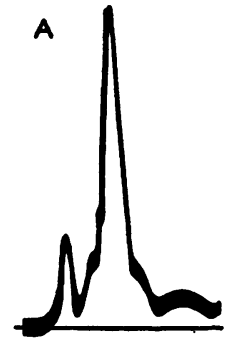

D

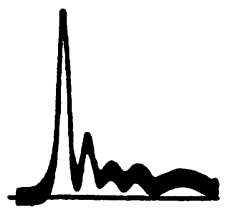

Fig. 3. Electrophoretic Patterns of Serum and Urinary Proteins of Case I

A. control serum, B. serum $\frac{1}{2}$ hour after injection, C. serum 48 hours after injection. Urinary protein patterns $D, E$, and $F$, correspond in time to the serum patterns above.
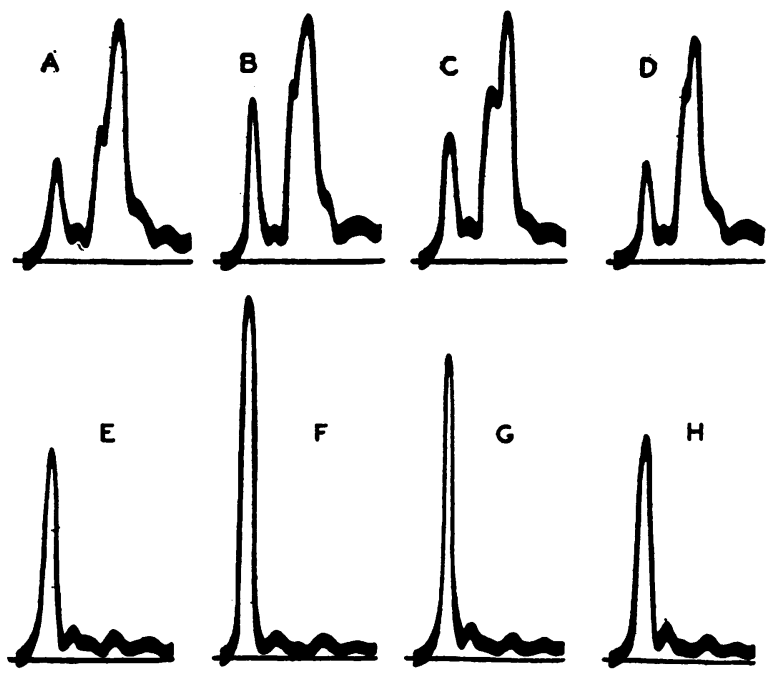

Fig. 4. Electrophoretic Patterns of Serum and Urinary Proteins of Case II

A. control serum, B. serum 1 hour after injection, C. serum 24 hours after injection, D. serum 48 hours after injection. Urinary protein patterns $E, F, G$, and $H$ correspond in time to the serum patterns above.
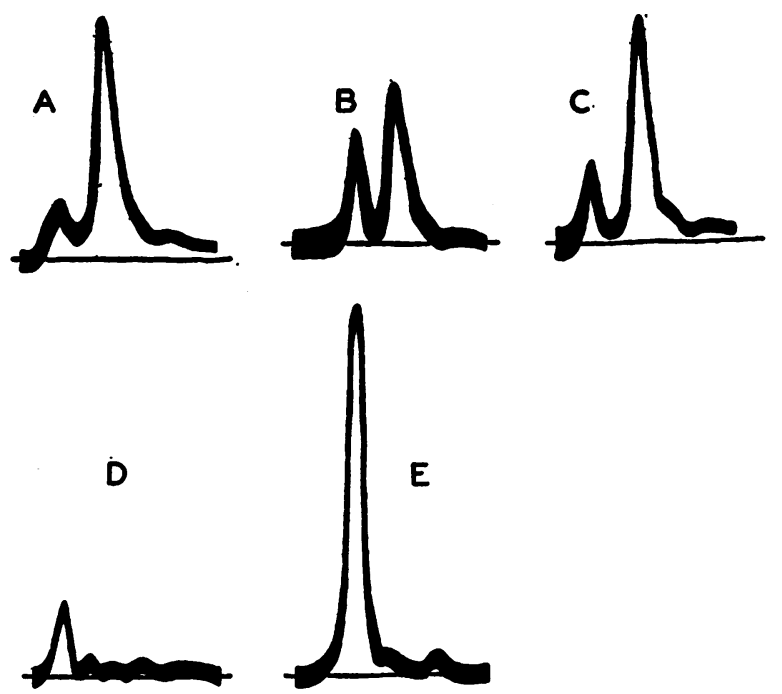

Fig. 5. Electrophoretic Patterns of Serum and Urinary Proteins of Case III

A. control serum, B. serum $\frac{1}{2}$ hour after injection, C. serum 24 hours after injection. Urinary protein patterns $\mathrm{D}$ and $\mathrm{E}$ correspond in time to the serum patterns above.

min injection, and for one hour afterward, the clearance of albumin was apparently increased; but because of the rapid shifts of protein, it is difficult to be certain of the mean serum albumin concentration. The clearance of total protein varies with the proportion of albumin in the serum, since the albumin clearance is much larger than the globulin clearance.

Clearance of the blue dye T-1824. The renal clearance of $\mathrm{T}-1824$ from the plasma of these patients with nephrosis is proportional to the protein clearance and approximately four times as large, exceeding even the albumin clearance after injection of albumin.

Effect of albumin injection on fluid and salt excretion. Although a larger volume of urine appeared on the day of albumin injection, no increase in the daily excretion of sodium or chloride was noted. In case III, the mannitol clearance was increased following the injection of albumin, but the chloride clearance fell somewhat.

\section{DISCUSSION}

The magnitude of the osmotic forces set in motion by the injection of concentrated serum albumin,"combined with the excess of interstitial fluid and the large deficit of blood volume, 
readily explains the dilution of the blood observed. The failure of the serum protein concentration to rise is somewhat misleading, for the colloid osmotic pressure of the serum is significantly increased by the greater proportion of albumin.

The failure of the albumin-globulin ratio to rise to the calculated level was not unexpected, for the same observation has been made after the injection of plasma $(2,3)$. In both cases, albumin is rapidly withdrawn from the circulation. There is one important difference, however, in the direction of change in the circulating globulin. In the 3 cases receiving albumin, the circulating globulin increased following the injection, whereas there is a gradual decrease in circulating globulin following the administration of plasma. If the increase in globulin proves to be a constant finding, it suggests an available reserve of serum globulin which can be rapidly introduced into the circulation. All fractions, including $\alpha_{1}$, are increased. The increased solubility of globulin in albumin solutions may play some rôle. The fluid with which the blood is diluted could scarcely contain the amounts of globulin involved. The conversion of albumin into globulin seems unlikely for many reasons, among which the most obvious are the rapidity of the exchange, the subsequent loss of globulin in the face of continued removal of albumin, and the maintenance of the same relative proportions of non-albumin fractions. In general, the observations suggest an equilibrium between circulating and reserve serum proteins, with a buffering of serum protein composition.

At the end of 1 or 2 days, only a small fraction of the injected albumin remained in the circulation. The loss of albumin in the urine was less than half of the quantity administered, and quite naturally varied inversely with the speed with which the albumin was removed from the plasma by the tissues, since these two routes of removal compete for a limited amount of albumin.

The 25 grams of serum albumin given to each of these patients represent $500 \mathrm{cc}$. of plasma or nearly a liter of blood. From the large proportion of the albumin removed from the circulation, it is evident that the equivalent of a number of liters of blood must be administered in order to produce clinical improvement, just as in the case of plasma.

Two major factors in the homeostasis of plasma protein concentration and distribution are evident in these experiments. The plasma volume can expand and contract to allow large changes in total circulating protein without significant change in protein concentration. The other stabilizing factor is the ability of the tissues to take up an excess of injected protein of one type and perhaps also to contribute small amounts of the other fractions, thus minimizing the change in the proportions of different fractions.

\section{SUMMARY}

The administration of a single injection of 25 grams of concentrated serum albumin was followed in 3 nephrotic patients by

(1) A rapid increase of plasma volume by 25 to 30 per cent of the original volume.

(2) A rise in the colloid osmotic pressure of the serum to 10 and 20 per cent above the original pressure (two patients).

(3) Small, variable changes in total serum protein concentration.

(4) An increase in circulating albumin which was always considerably less than the amount injected.

(5) A small but consistent increase in circulating globulin.

(6) An increased proteinuria due to the higher proportion of serum albumin with little change in albumin and globulin clearance, calculated on a daily basis.

(7) A small increase in urine volume but no rise in chloride excretion.

(8) No clinical benefit, inasmuch as the amounts given were far too small to produce any permanent change.

Within 48 hours after the injection, most of the effects had disappeared. The largest fraction of the injected protein had been removed from the circulation and was not to be found in the urine.

\section{CONCLUSIONS}

1. Further evidence has been presented for the equilibrium between circulating and tissue proteins. 
2. As in the case of plasma, the equivalent in serum albumin of nearly a liter of normal blood fails to produce a persistent elevation of the circulating serum albumin in severe hypoproteinemia.

3. The deficit of red blood cell volume in patients with the nephrotic syndrome is again demonstrated. The concentration of red blood cells is further depressed when the plasma volume is increased by the administration of serum albumin.

4. The proteinuria in these patients could be related to the concentration of serum albumin and globulin by relatively constant renal clearances of albumin and globulin. The fraction designated $\alpha_{1}$ resembles albumin in its clearance.

\section{BIBLIOGRAPHY}

1. Aldrich, C. A., Stokes, J., Jr., Killingsworth, W. P., and McGuiness, A. C., Concentrated human blood serum as a diuretic in the treatment of nephrosis. J. A. M. A., 1938, 111, 129.

2. Weech, A. A., Goettsch, E., and Lyttle, J. D., Intravenous injection of serum and acacia in the treat- ment of edema. M. Clin. North America, 1940, 24, 807.

3. Brown, H., Gray, C. H., and Mollison, P. L., Treatment of the nephrotic syndrome with serum transfusions. Brit. M. J., 1942, 1, 515.

4. Weech, A. A., Goettsch, E., and Reeves, E. B., The effect of serum transfusion on the plasma protein depletion associated with nutritional edema in dogs. J. Clin. Invest., 1933, 12, 217.

5. Cohn, E. J., et al., Preparation and properties of serum and plasma proteins. III. Size and charge of proteins separating upon equilibration across membranes with ethanol-water mixtures of controlled $\mathrm{pH}$, ionic strength and temperature. J. Am. Chem. Soc., 1940, 62, 3396.

6. Longsworth, L. G., Recent advances in the study of proteins by electrophoresis. Chem. Rev., 1942, 30, 323.

7. Luetscher, J. A., Jr., Electrophoretic analysis of plasma and urinary proteins. J. Clin. Invest., 1940, 19, 313.

8a. Hepp, O., Ein neues Onkometer zur Bestimmung des Kolloid-osmotischen Druckes mit gesteigerter Messgenauigkeit und vereinfachter Handhabung. Ztschr. f. d. ges. exp. Med., 1936, 99, 709.

b. Peters, E., and Saslow, G., Performance of the Hepp micro-osmometer. J. Gen. Physiol., 1939, 23, 177. 